Supplement of Biogeosciences, 17, 4571-4589, 2020

https://doi.org/10.5194/bg-17-4571-2020-supplement

(C) Author(s) 2020. This work is distributed under

the Creative Commons Attribution 4.0 License.

(c) (1)

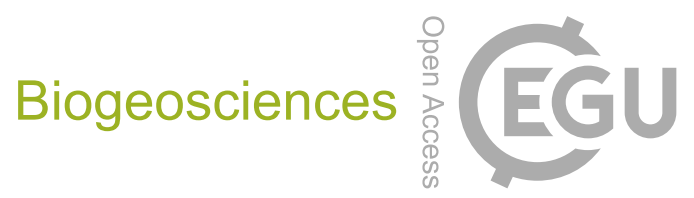

Supplement of

\title{
Mineralization of organic matter in boreal lake sediments: rates, pathways, and nature of the fermenting substrates
}

François Clayer et al.

Correspondence to: François Clayer (francois.clayer@niva.no)

The copyright of individual parts of the supplement might differ from the CC BY 4.0 License. 


\section{S1. Additional figures}

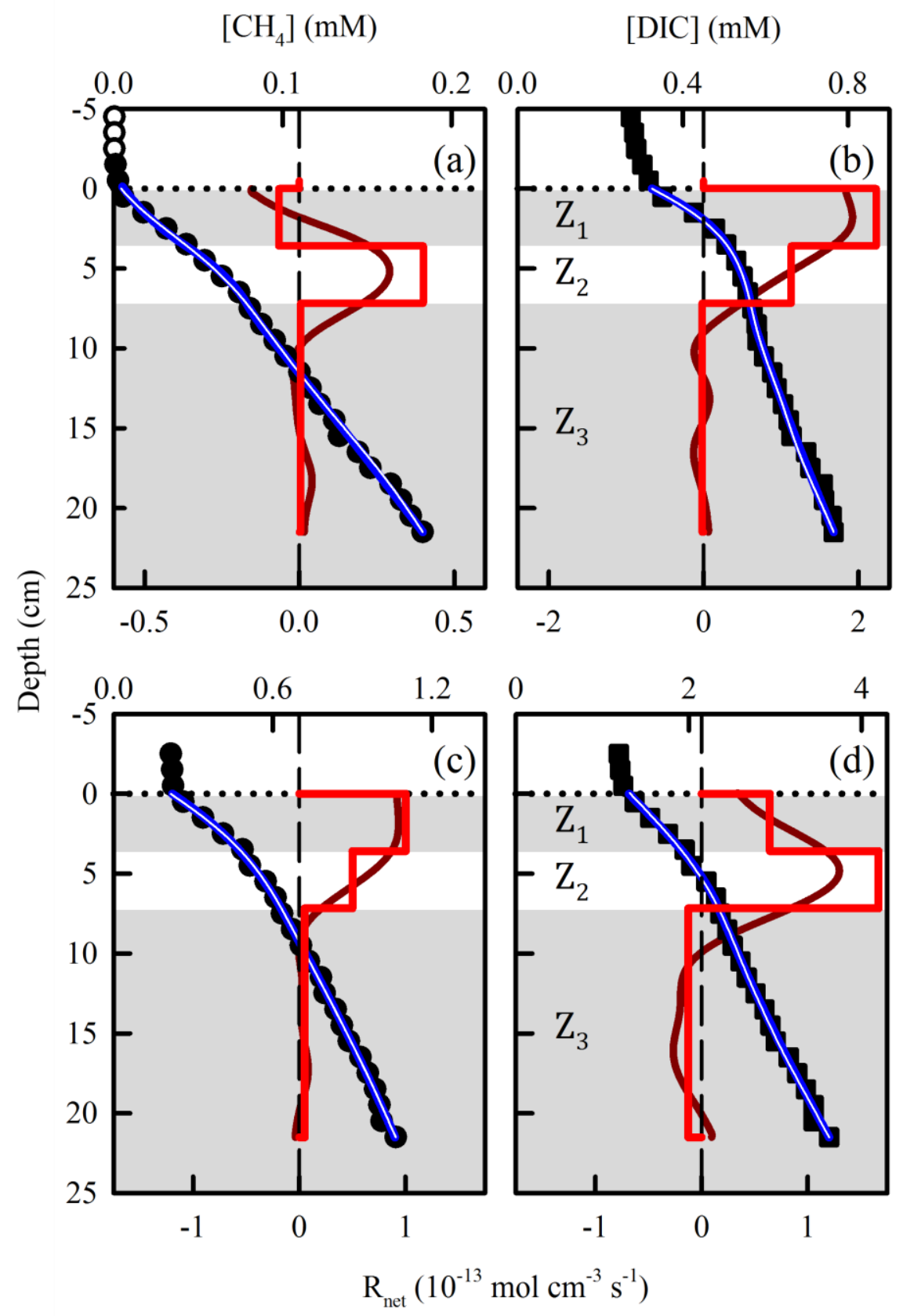

Figure S1: Comparison of concentration profiles generated with the codes PROFILE (blue line) and REC (white line) with the average $(n=3)$ measured concentrations (symbols) of $\mathrm{CH}_{4}$ (a and c) and DIC (b and d) for Lake Tantaré Basin A (a and b) and Lake Bédard (c and d). The horizontal dotted line indicates the sediment-water interface. The thick red (PROFILE) and dark red (REC) lines represent the net solute reaction rate profiles. 


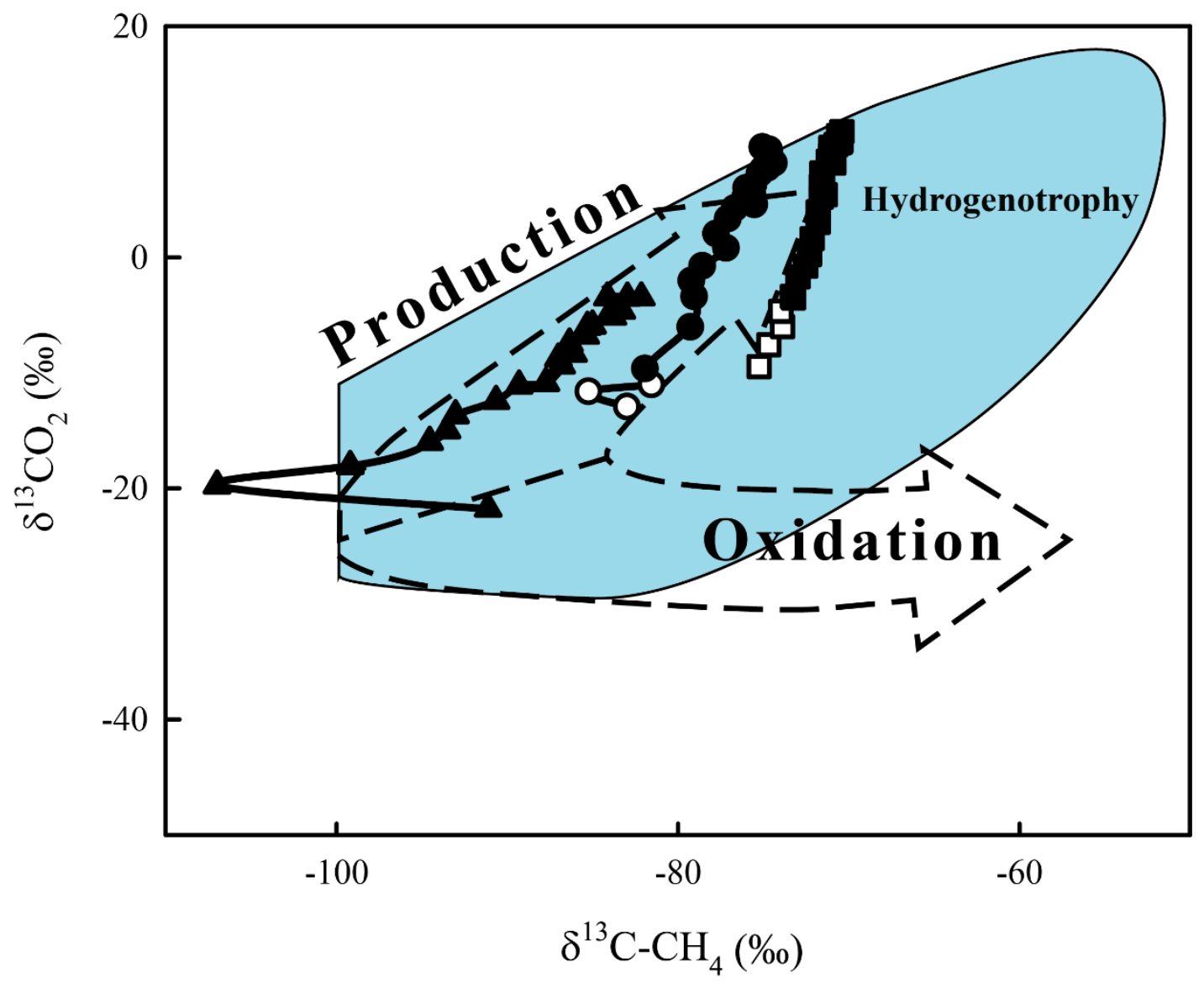

Figure S2: $\delta^{13} \mathrm{C}-\mathrm{CH}_{4}$ versus $\delta^{13} \mathrm{CO}_{2}$ graph showing the hydrogenotrophy (blue) domain (modified from Whiticar 1999) along with the measured $\delta^{13} \mathbf{C}$ data (symbols) in Lake Tantaré Basin A (triangles) and Basin B (squares; data from Clayer et al., 2018), and in Lake Bédard (circles). Empty symbols correspond to datapoints above the sediment-water interface. The $\delta^{13} \mathrm{C}$ of gaseous $\mathrm{CO}_{2}\left(\delta^{13} \mathrm{CO}_{2}\right.$ on the vertical axis) was calculated from the $\delta^{13} \mathrm{C}$-DIC according to Hélie (2004) and Mook et al. (1974). 


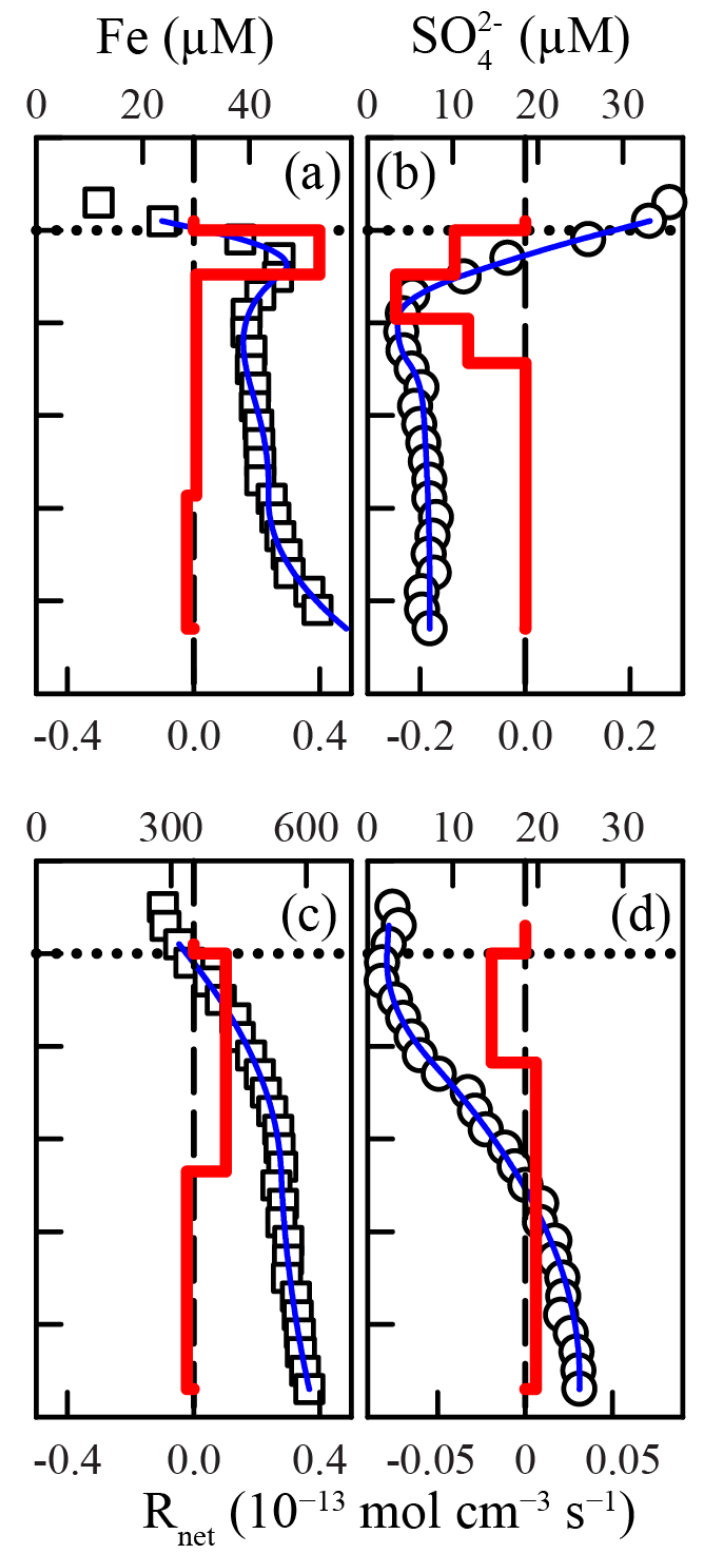

Figure S3: Comparison of the modeled (blue lines) and average $(n=3)$ measured (symbols) concentration profiles of $\mathrm{SO}_{4}(\mathrm{a}$ and c) and Fe (b and d) in Lakes Tantaré Basin A (a-b) and Bédard (c-d). The horizontal dotted line indicates the sediment-water interface. The thick red lines represent the net solute reaction rate $\left(R_{\text {net }}^{\text {solute }}\right)$. 


\section{S2. Procedure for modeling the $\delta^{13} \mathrm{C}$ profiles}

Modeling the $\delta^{13} \mathrm{C}$ profiles with Eq. 7, as described in section 2.4, requires first obtaining accurate $[\mathrm{C}]$ and $\left[{ }^{13} \mathrm{C}\right]$ profiles by solving numerically, via the bvp5c function of MATLAB ${ }^{\circledR}$, Eqs. 2 and 7 for $[C]$ and $\left[{ }^{13} \mathrm{C}\right]$, respectively. Equation 2 is readily solved for [C] if we use in that equation the depth distributions of $\mathrm{R}_{\text {net }}^{\mathrm{CH}_{4}}$ or $\mathrm{R}_{\text {net }}^{\mathrm{DIC}}$ provided by the code PROFILE (Table 2) and those of $\mathrm{D}_{\mathrm{s}}$ and $\alpha_{\text {Irrigation }}$, and if we impose the measured $\mathrm{CH}_{4}$ or DIC concentrations at the top and bottom of their profiles as boundary conditions. The $\mathrm{CH}_{4}$ and DIC profiles simulated this way are very similar to those generated by the code PROFILE, and thus to the measured distributions of these two solutes. However, extracting truthful $\left[{ }^{13} \mathrm{C}\right]$ profiles from Eq. 7 is more complicated because it requires obtaining the best estimate values for the parameters $f, \delta^{13} C_{i}^{\text {reactant }}, \alpha_{i}$, and $R_{i}$ which are inherent to that equation. The approach adopted to select the best estimate values involves several steps described below.

\section{S2.1. Simulating the $\delta^{13} \mathrm{C}$ profiles with default parameter values in}

\section{Equation 7}

The first step is to perform an initial simulation of the $\delta^{13} \mathrm{C}$ profiles using credible values (hereafter referred to as default values) for the $f, \delta^{13} C_{i}^{\text {reactant }}, \alpha_{i}$, and $R_{i}$ in Eq. 7 . For the $\mathrm{f}, \delta^{13} \mathrm{C}_{\mathrm{i}}^{\text {reactant }}$ and $\alpha_{\mathrm{i}}$, the default values were educated guesses based on the literature. For the rates, they were $\mathrm{R}_{\mathrm{i}}$ values constrained with Eqs. 3-5 and the $\mathrm{R}_{\text {net }}^{\mathrm{CH}_{4}}, \mathrm{R}_{\text {net }}^{\mathrm{DIC}}$ and $\mathrm{R}_{\text {net }}^{\mathrm{Xx}}$ values provided by PROFILE (Table 2). 


\section{S2.1.1. Default values for the $f, \delta^{13} C_{i}^{\text {reactant }}$ and $\alpha_{i}$}

The values reported in the literature for the $\mathrm{f}-\mathrm{CH}_{4}$ and $\mathrm{f}-\mathrm{DIC}$ as well as for the $\delta^{13} C_{i}^{\text {reactant }}$ and the $\alpha_{i}$ of each of the $r_{i}$ outlined in Table 1 , are summarized in Table $S 1$ together with the default values. The value of $\mathrm{f}-\mathrm{CH}_{4}$ was estimated to be less than 1.003 (Happell et al., 1995), and that of f-DIC, lower than 1.001 (O'Leary, 1984; Jähne et al., 1987). Consequently, we chose 1.000 as the default value for both. The values of $\delta^{13} \mathrm{C}_{\mathrm{i}}^{\text {reactant }}$ used were $-28 \%$ for OM (Joshani, 2015), and $-38 \%$ and $-18 \%$ or the methyl and carboxyl groups of acetate (Conrad et al., 2014), respectively, and the measured $\delta^{13} \mathrm{C}$ values for $\mathrm{CH}_{4}$ and DIC. We assumed no carbon fractionation during $\mathrm{OM}$ fermentation and oxidation, i.e., $\alpha_{1}=\alpha_{2}=\alpha_{6}=1.000$ (Lapham et al., 1999). Methane produced through acetoclasty (r3) and hydrogenotrophy (r4) is typically depleted in ${ }^{13} \mathrm{C}$ by $21-27 \%$ and $50-95 \%$, respectively (i.e., $\alpha_{3}-\mathrm{CH}_{4}$ and $\alpha_{4}$ ranges are $1.021-1.027$ and 1.050-1.095, respectively) compared to its substrate (Krzycki et al., 1987; Gelwicks et al., 1994; Whiticar, 1999). In addition, $\mathrm{CO}_{2}$ and $\mathrm{CH}_{4}$ production through acetoclasty appears to undergo similar ${ }^{13} \mathrm{C}$ depletion (Blair and Carter, 1992; Gelwicks et al., 1994). Consequently, the same intermediate fractionation factor was chosen as the default value for $\alpha_{3}-\mathrm{CH}_{4}$ and $\alpha_{3}-\mathrm{CO}_{2}$, i.e., 1.024. In agreement with Conrad et al. (2014), we used 1.075 as the default value for $\alpha_{4}$. Several studies showed that $\alpha_{5}$ can vary from 1.005 to 1.031 (Alperin et al., 1988; Whiticar, 1999); a default value of 1.005 was selected as in Whiticar and Faber (1986). For siderite precipitation, we calculated a composite $\alpha_{7}$ value using the fractionation factors reported for calcite precipitation from $\mathrm{CO}_{2}(0.990)$ or from $\mathrm{HCO}_{3}^{-}(0.998)$ and taking into account the relative proportion of $\mathrm{HCO}_{3}^{-}$and $\mathrm{CO}_{2}$ concentrations (Bottinga, 1969; Emrich et al., 1970). 


\section{S2.1.2. Default values for the $R_{i}$}

Given that methanogenesis is dominated by hydrogenotrophy (see section 3.3), and that porewaters in all sediment zones at Lake Tantare Basin $A$ and in the $Z_{1}$ and $Z_{2}$ at Lake Bédard are undersaturated with respect to siderite, we assume that $R_{3}=R_{7}=0$ in all the zones of the two lake basins. The only exception is for the $Z_{3}$ of Lake Bédard where we infer that siderite is precipitating (see details below). In addition, we consider that $\mathrm{R}_{2}=0$ in all the zones of the two lake basins, except in the $Z_{2}$ of Lake Bédard where reaction $r 2$ is required to explain the DIC net production rate (see details below). The default $\mathrm{R}_{\mathrm{i}}$ values, obtained as described below, are reported in Table S2.

Table S1: Values of the $\delta^{13} \mathrm{C}$ of organic matter (OM), the carboxyl group (Ac-carboxyl) and the methyl group (Ac-methyl) of acetate, and those of the molecular diffusivity ratios (f) and the isotopic fractionation factors $\left(\alpha_{i}\right)$ used as input parameters in Eq. 7.

\begin{tabular}{lccc}
\hline \multicolumn{1}{c}{ Parameters } & Range & References & Default \\
\hline$\delta^{13} \mathrm{C}$ of OM (\%o V-PDB) & -28 & $\mathrm{a}$ & -28 \\
$\delta^{13} \mathrm{C}$ of Ac-carboxyl (\%o V-PDB) & -18 & $\mathrm{~b}, \mathrm{c}$ & -18 \\
$\delta^{13} \mathrm{C}$ of Ac-methyl (\%o V-PDB) & -38 & $\mathrm{~b}, \mathrm{c}$ & -38 \\
$\mathrm{f}-\mathrm{DIC}$ & $1.000-1.001$ & $\mathrm{~d}, \mathrm{e}$ & 1.000 \\
$\mathrm{f}-\mathrm{CH}_{4}$ & $1.000-1.003$ & $\mathrm{f}$ & 1.000 \\
$\alpha_{1}, \alpha_{2}$ and $\alpha_{6}$ & 1.000 & $\mathrm{~g}, \mathrm{~h}, \mathrm{i}$ & 1.000 \\
$\alpha_{3}-\mathrm{CH}_{4}$ & $1.021-1.027$ & $\mathrm{j}, \mathrm{k}, \mathrm{l}$ & 1.024 \\
$\alpha_{3}-\mathrm{CO}_{2}$ & $1.021-1.027$ & $\mathrm{k}, \mathrm{m}$ & 1.024 \\
$\alpha_{4}$ & $1.050-1.095$ & $1, \mathrm{c}$ & 1.075 \\
$\alpha_{5}$ & $1.005-1.031$ & $1, \mathrm{n}, \mathrm{o}$ & 1.005 \\
$\alpha_{7}$ & $0.990-0.998$ & $\mathrm{p}, \mathrm{q}$ & 0.995 \\
\hline
\end{tabular}

References: (a) Joshani (2015), (b) Conrad et al (2007), (c) Conrad et al. (2014), (d) O'Leary (1984), (e) Jähne et al. (1987), (f) Happell et al., 1995, (g) Lapham et al. (1999), (h) Werth and Kusyakov (2010), (i) Conrad et al. (2012), (j) Krzycki et al. (1987), (k) Gelwicks et al. (1994), (l) Whiticar (1999), (m) Blair and Carter (1992), (n) Alperin et al. (1988), (o) Whiticar and Faber (1986), (p) Bottinga (1969), (q) Emrich et al. (1970). 


\section{S2.1.2.1. Zone of net methanotrophy}

According to Fig. $2 \mathrm{~g}$ and o, net methanotrophy is observed only in the $Z_{1}(0-$ $3.6 \mathrm{~cm}$ ) of Lake Tantaré Basin A. The net rate of DIC production in that zone (223 fmol $\left.\mathrm{cm}^{-3} \mathrm{~s}^{-1}\right)$ is much larger than the net rate of $\mathrm{CH}_{4}$ consumption $\left(7 \mathrm{fmol} \mathrm{cm}{ }^{-3} \mathrm{~s}^{-1}\right)$ as reported in Table 2. According to Eqs. 3 and 4, the difference between the net rates of $\mathrm{DIC}$ and $\mathrm{CH}_{4}$ production is:

$$
\mathrm{R}_{\mathrm{net}}^{\mathrm{DIC}}-\mathrm{R}_{\mathrm{net}}^{\mathrm{CH}_{4}}=\mathrm{R}_{1}+\mathrm{R}_{2}-2 \mathrm{R}_{4}+2 \mathrm{R}_{5}+\mathrm{R}_{6}
$$

Given the large net rate of oxidant consumption $\left(\mathrm{R}_{\mathrm{net}}^{\mathrm{Ox}}=-335 \mathrm{fmol} \mathrm{cm}^{-3} \mathrm{~s}^{-1}\right)$, we assume that the contribution of $\mathrm{R}_{2}$ in Eq. $\mathrm{S} 1$ can be neglected compared to that of the oxidative processes $\left(2 R_{5}+R_{6}\right)$. In addition, the differences between the values of the $\delta^{13} \mathrm{CO}_{2}$ and those of the $\delta^{13} \mathrm{C}-\mathrm{CH}_{4}(67-92 \%)$, the large ${ }^{13} \mathrm{C}-\mathrm{CH}_{4}$ negative values (-91 to $-107 \%$ ) and their upward depletion between 4.5 and $2.5 \mathrm{~cm}$ depth (Fig. $2 \mathrm{~b}$ ), as well as the fact that these isotopic data fall in the $\mathrm{CO}_{2}$ reduction domain (Fig. S2), all indicate that $\mathrm{CH}_{4}$ production by hydrogenotrophy is also active in the $\mathrm{Z}_{1}$ of Lake Tantare Basin $\mathrm{A}$, i.e., that $\mathrm{R}_{4} \neq 0$. To simplify, we assume for now that the main oxidative process is methanotrophy and that the contribution of $\mathrm{R}_{6}$ in Eq. $\mathrm{S} 1$ is negligible compared to that of $2 \mathrm{R}_{5}$; the effect of a possible contribution of OM oxidation to DIC will be considered in section S2.2.2.2. With the assumption that $\mathrm{R}_{2}=\mathrm{R}_{3}=\mathrm{R}_{6}=\mathrm{R}_{7}=0$, we obtain from Eq. 3-5 the default values $\mathrm{R}_{1}=216 \mathrm{fmol} \mathrm{cm} \mathrm{cm}^{-3}, \mathrm{R}_{4}=161 \mathrm{fmol} \mathrm{cm}^{-3} \mathrm{~s}^{-1}$ and $\mathrm{R}_{5}=168 \mathrm{fmol}$ $\mathrm{cm}^{-3} \mathrm{~s}^{-1}$ 
Table S2: Rates $\left(R_{1}-R_{7} ;\right.$ fmol $\left.\mathrm{cm}^{-3} \mathrm{~s}^{-1}\right)$ of reactions involved in $O M$ mineralization and of siderite precipitation in each sediment zone of the two sampling sites. For each reaction rate, a default value is given and, when applicable, the range of rate values tested in modeling the $\delta^{13} C$ profiles. $\chi_{M}$ and $\chi_{H}$ are the fractions of oxidants consumed by methanotrophy and of $\mathrm{CH}_{4}$ produced by hydrogenotrophy, respectively.

\begin{tabular}{|c|c|c|c|c|c|}
\hline \multirow[b]{2}{*}{ Zones } & & \multicolumn{2}{|r|}{ Lake Tantaré Basin A } & \multicolumn{2}{|r|}{ Lake Bédard } \\
\hline & & Default & Range $^{\mathrm{a}}$ & Default & Range \\
\hline \multirow[t]{7}{*}{$\mathrm{Z}_{1}$} & $\mathrm{R}_{1}$ & 216 & $-105+\chi_{H}\left(335 \chi_{M}-14\right)$ & 165 & $-35+200 \chi_{\mathrm{H}}$ \\
\hline & $\mathrm{R}_{2}$ & 0 & & 0 & \\
\hline & $\mathrm{R}_{3}$ & 0 & $\left(1-\chi_{H}\right)\left(\frac{335}{2} \chi_{M}-7\right)$ & 0 & $100-100 \chi_{H}$ \\
\hline & $\mathrm{R}_{4}$ & 161 & $\chi_{H}\left(\frac{335}{2} \chi_{M}-7\right)$ & 100 & $100 \chi_{\mathrm{H}}$ \\
\hline & $\mathrm{R}_{5}$ & 168 & $\frac{335}{2} \chi_{M}$ & 0 & \\
\hline & $\mathrm{R}_{6}$ & 0 & $335-335 \chi_{M}$ & 0 & \\
\hline & $\mathrm{R}_{7}$ & 0 & & 0 & \\
\hline \multirow[t]{7}{*}{$\mathrm{Z}_{2}$} & $\mathrm{R}_{1}$ & 152 & $-29+\chi_{\mathrm{H}}\left(78+103 \chi_{\mathrm{M}}\right)$ & 100 & $\frac{100 \operatorname{Cos}\left(\chi_{\mathrm{H}}-1\right)-400 \chi_{\mathrm{H}}}{\cos -4}$ \\
\hline & $\mathrm{R}_{2}$ & 0 & & 117 & $117+100 \chi_{\mathrm{H}}-\mathrm{R}_{1}$ \\
\hline & $\mathrm{R}_{3}$ & 0 & $\left(1-\chi_{H}\right)\left(39+\frac{103}{2} \chi_{M}\right)$ & 0 & $50-50 \chi_{\mathrm{H}}$ \\
\hline & $\mathrm{R}_{4}$ & 90.5 & $\chi_{H}\left(39+\frac{103}{2} \chi_{M}\right)$ & 50 & $50 \chi_{H}$ \\
\hline & $\mathrm{R}_{5}$ & 51.5 & $\frac{103}{2} \chi_{M}$ & 0 & \\
\hline & $\mathrm{R}_{6}$ & 0 & $103-103 \chi_{M}$ & 0 & \\
\hline & $\mathrm{R}_{7}$ & 0 & & 0 & \\
\hline \multirow[t]{7}{*}{$\mathrm{Z}_{3}$} & $\mathrm{R}_{1}$ & 0 & & 0 & \\
\hline & $\mathrm{R}_{2}$ & 0 & & 0 & \\
\hline & $\mathrm{R}_{3}$ & 0 & & 0 & \\
\hline & $\mathrm{R}_{4}$ & 1 & & 5 & \\
\hline & $\mathrm{R}_{5}$ & 0 & & 0 & \\
\hline & $\mathrm{R}_{6}$ & 0 & & 0 & \\
\hline & $\mathrm{R}_{7}$ & 0 & & 8 & \\
\hline
\end{tabular}

${ }^{a}$ Note that $\chi_{M}$ cannot take values below 0.36 to avoid negative rate values for $R_{1}$ according to Equation $S 8$. 


\section{S2.1.2.2. Zones of net methanogenesis}

Figure $2 \mathrm{~g}-\mathrm{h}$ and Table 2 indicate that the value of the $\mathrm{R}_{\mathrm{net}}^{\mathrm{DIC}}\left(113 \mathrm{fmol} \mathrm{cm}^{-3} \mathrm{~s}^{-1}\right)$ is much larger than that of the $\mathrm{R}_{\text {net }}^{\mathrm{CH}_{4}}\left(39 \mathrm{fmol} \mathrm{cm}^{-3} \mathrm{~s}^{-1}\right)$ for the $\mathrm{Z}_{2}$ of Lake Tantare Basin $\mathrm{A}$. Since oxidants are consumed at a substantial rate $\left(\mathrm{R}_{\text {net }}^{\mathrm{Ox}}=-103 \mathrm{fmol} \mathrm{cm} \mathrm{c}^{-3} \mathrm{~s}^{-1}\right.$; Table 2$)$, we conclude that DIC must be mainly produced through oxidation of $\mathrm{CH}_{4}$ and/or $\mathrm{OM}$ (e.g., $\mathrm{r} 5$ and/or r6 in Table 1) in addition to fermentation (r1) and that $\mathrm{R}_{2}$ can be neglected in Eq. S1. For now, we assume, as for the $\mathrm{Z}_{1}$ of Lake Tantare Basin $\mathrm{A}$, that the only source of DIC in addition to fermentation ( $\mathrm{r} 1)$ is methanotrophy, and thus that $\mathrm{R}_{6}=0$; the effect of a possible contribution of $\mathrm{r} 6$ to DIC will be considered in section S2.2.2.2. Thus, with the assumptions $\mathrm{R}_{2}=\mathrm{R}_{3}=\mathrm{R}_{6}=\mathrm{R}_{7}=0$, we obtain from Eqs. $3-5$ the default

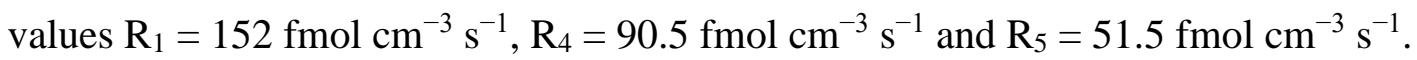

Note that $\mathrm{R}_{1}>\mathrm{R}_{4}$ does not necessarily mean that the sum of fermentation (r1) and methanogenesis via $\mathrm{CO}_{2}$ reduction (r4) produces more DIC than $\mathrm{CH}_{4}$ since the net rates of DIC and $\mathrm{CH}_{4}$ production by the coupling of these two reactions are equal to $\mathrm{R}_{1}-\mathrm{R}_{4}$ and $\mathrm{R}_{4}$, respectively. For example, when glucose $\left(\mathrm{C}_{6} \mathrm{H}_{12} \mathrm{O}_{6}\right)$ is the fermenting substrate, the coupling of $\mathrm{r} 1$ and $\mathrm{r} 4$ produces equimolar amounts of $\mathrm{CH}_{4}$ and DIC, i.e., $\mathrm{R}_{\text {net }}^{\mathrm{CH}_{4}}=$ $\mathrm{R}_{\text {net }}^{\mathrm{DIC}}$, and the value of $\mathrm{R}_{1}$ is then equal to twice that of $\mathrm{R}_{4}\left(\mathrm{R}_{1}=2 \mathrm{R}_{4}\right)$. The case when $\mathrm{R}_{1}<$ $2 R_{4}$ is discussed in section 4 while the case when $R_{1}>2 R_{4}$ is discussed below.

For the $\mathrm{Z}_{1}$ of Lake Bédard, the $\mathrm{R}_{\text {net }}^{\mathrm{CH}_{4}}\left(100 \mathrm{fmol} \mathrm{cm}^{-3} \mathrm{~s}^{-1}\right)$ and the $\mathrm{R}_{\text {net }}^{\mathrm{DIC}}$ (65 fmol cm $\left.\mathrm{cm}^{-3} \mathrm{~s}^{-1}\right)$ are much larger than the $\mathrm{R}_{\text {net }}^{\text {Ox }}\left(-6.5 \mathrm{fmol} \mathrm{cm}^{-3} \mathrm{~s}^{-1}\right)$, suggesting that the reaction rates of the oxidative processes $R_{5}$ and $R_{6}$ can be neglected in these reduced sediments. Thus, if we assume that $R_{2}=R_{3}=R_{5}=R_{6}=R_{7}=0$, Eqs. 3 and 4 yield $R_{1}$ $=165 \mathrm{fmol} \mathrm{cm}^{-3} \mathrm{~s}^{-1}$ and $\mathrm{R}_{4}=100 \mathrm{fmol} \mathrm{cm} \mathrm{cm}^{-3} \mathrm{~s}^{-1}$ as default values. 
For the $\mathrm{Z}_{2}$ of Lake Bédard, $\mathrm{R}_{\text {net }}^{\mathrm{OX}}\left(-4.5 \mathrm{fmol} \mathrm{cm}{ }^{-3} \mathrm{~s}^{-1}\right)$ is much smaller than $\mathrm{R}_{\text {net }}^{\mathrm{CH}_{4}}$ (50 fmol cm $\mathrm{cm}^{-1}$ ) and $\mathrm{R}_{\mathrm{net}}^{\mathrm{DIC}}\left(167 \mathrm{fmol} \mathrm{cm}{ }^{-3} \mathrm{~s}^{-1}\right)$, indicating that, as in the $\mathrm{Z}_{1}, \mathrm{R}_{5}$ and $\mathrm{R}_{6}$ can be neglected. With the assumptions that $R_{3}=R_{5}=R_{6}=R_{7}=0$, we obtain from Eqs. 3 and 4 the default values $R_{1}+R_{2}=217 \mathrm{fmol} \mathrm{cm}^{-3} \mathrm{~s}^{-1}$ and $\mathrm{R}_{4}=$ $50 \mathrm{fmol} \mathrm{cm}^{-3} \mathrm{~s}^{-1}$. In this case DIC production rate is more than four times larger than $\mathrm{R}_{4}\left(\mathrm{R}_{\text {net }}^{\mathrm{DIC}} \gg 2 \mathrm{R}_{4}\right.$ ), which cannot be explained by methanogenesis alone or, given the low $\mathrm{R}_{\mathrm{net}}^{\mathrm{Ox}}$, by oxidation reactions. Similar unanticipated DIC production has been previously attributed to the partial fermentation of HMW OM (r2, Corbett et al., 2015). Calculating individual default values for $\mathrm{R}_{1}$ and $\mathrm{R}_{2}$ requires an assumption about the nature of the fermenting substrate. For now, we assume that glucose is that substrate. i.e., that $\mathrm{R}_{1}=$ $2 \mathrm{R}_{4}$; the effect of considering more reduced fermenting substrates will be examined in section $\mathrm{S} 2.2 .2 .3$. With this latter assumption, the default values $\mathrm{R}_{1}=100 \mathrm{fmol} \mathrm{cm} \mathrm{f} \mathrm{s}^{-1}$ and $\mathrm{R}_{2}=117 \mathrm{fmol} \mathrm{cm} \mathrm{s}^{-1}$ are obtained.

Finally, in the $Z_{3}$ of each lake basin, the net DIC consumption rate $\left(2 \mathrm{fmol} \mathrm{cm}{ }^{-3}\right.$ $\mathrm{s}^{-1}$ and $13 \mathrm{fmol} \mathrm{cm}^{-3} \mathrm{~s}^{-1}$, for Lake Tantaré Basin A and Lake Bédard, respectively) and the simultaneous net $\mathrm{CH}_{4}$ production rate $\left(1 \mathrm{fmol} \mathrm{cm}^{-3} \mathrm{~s}^{-1}\right.$ and $5 \mathrm{fmol} \mathrm{cm}^{-3} \mathrm{~s}^{-1}$, for Lake Tantaré Basin A and Lake Bédard, respectively) indicate that hydrogenotrophy is active in these zones. The negative values of the $\mathrm{R}_{\text {net }}^{\mathrm{DIC}}$ and the fact that the $\mathrm{R}_{\text {net }}^{\mathrm{OX}}=0$ suggest that the rates of the reactions producing DIC, i.e., $\mathrm{r} 1, \mathrm{r} 2, \mathrm{r} 5$ and $\mathrm{r} 6$, can be neglected. The presence of DIC in the $Z_{3}$ is likely due to its diffusion from deeper porewater (Fig. 2c and k), but not to its production in the $Z_{3}$ through the reactions listed in Table 1. Considering that $R_{1}=R_{2}=R_{5}=R_{6}=0$, the value of $R_{4}$ is estimated with Eq. 3 to be $1 \mathrm{fmol} \mathrm{cm}^{-3}$ $\mathrm{s}^{-1}$ and $5 \mathrm{fmol} \mathrm{cm}{ }^{-3} \mathrm{~s}^{-1}$, for Lake Tantaré Basin A and Lake Bédard, respectively. Note 
that in the $\mathrm{Z}_{3}$ of Lake Bédard, the net rate value of DIC consumption exceeds by $8 \mathrm{fmol} \mathrm{cm}^{-3} \mathrm{~s}^{-1}$ that of $\mathrm{CH}_{4}$ production suggesting that DIC is consumed by another process, in addition to hydrogenotrophy. Given that porewater is oversaturated with respect to siderite in that zone (see section 2.4) and that modeling the average $\mathrm{Fe}$ concentration profiles with the code PROFILE yields a net Fe consumption rate of -3 fmol cm $\mathrm{cm}^{-3} \mathrm{~s}^{-1}$ only in that zone (data not shown), we infer that siderite is precipitating at a rate of $8 \mathrm{fmol} \mathrm{cm}^{-3} \mathrm{~s}^{-1}$ in the $\mathrm{Z}_{3}$ of Lake Bédard, i.e., $\mathrm{R}_{7}=8 \mathrm{fmol} \mathrm{cm} \mathrm{cm}^{-3} \mathrm{~s}^{-1}$.

\section{S2.1.3. Modeled $\delta^{13} \mathrm{C}$ profiles with the default values}

The measured (symbols) $\delta^{13} \mathrm{C}$ profiles and those simulated with the default values (purple lines) are displayed in Figure S3. A simulated profile is considered acceptable when it falls within the variability related to the sediment heterogeneity at the sampling sites (grey area fills in Fig. S3). Fig. S3a and b shows that the $\delta^{13} \mathrm{C}$ profiles modeled with the default values do not fit adequately the datapoints in both lake basins except for the

$\delta^{13} \mathrm{C}-\mathrm{CH}_{4}$ profile in Lake Bédard. These discrepancies can be due to inaccuracy of the default $f$ and $\alpha_{i}$ and in the $R_{i}$ values, a possibility that is tested below. 


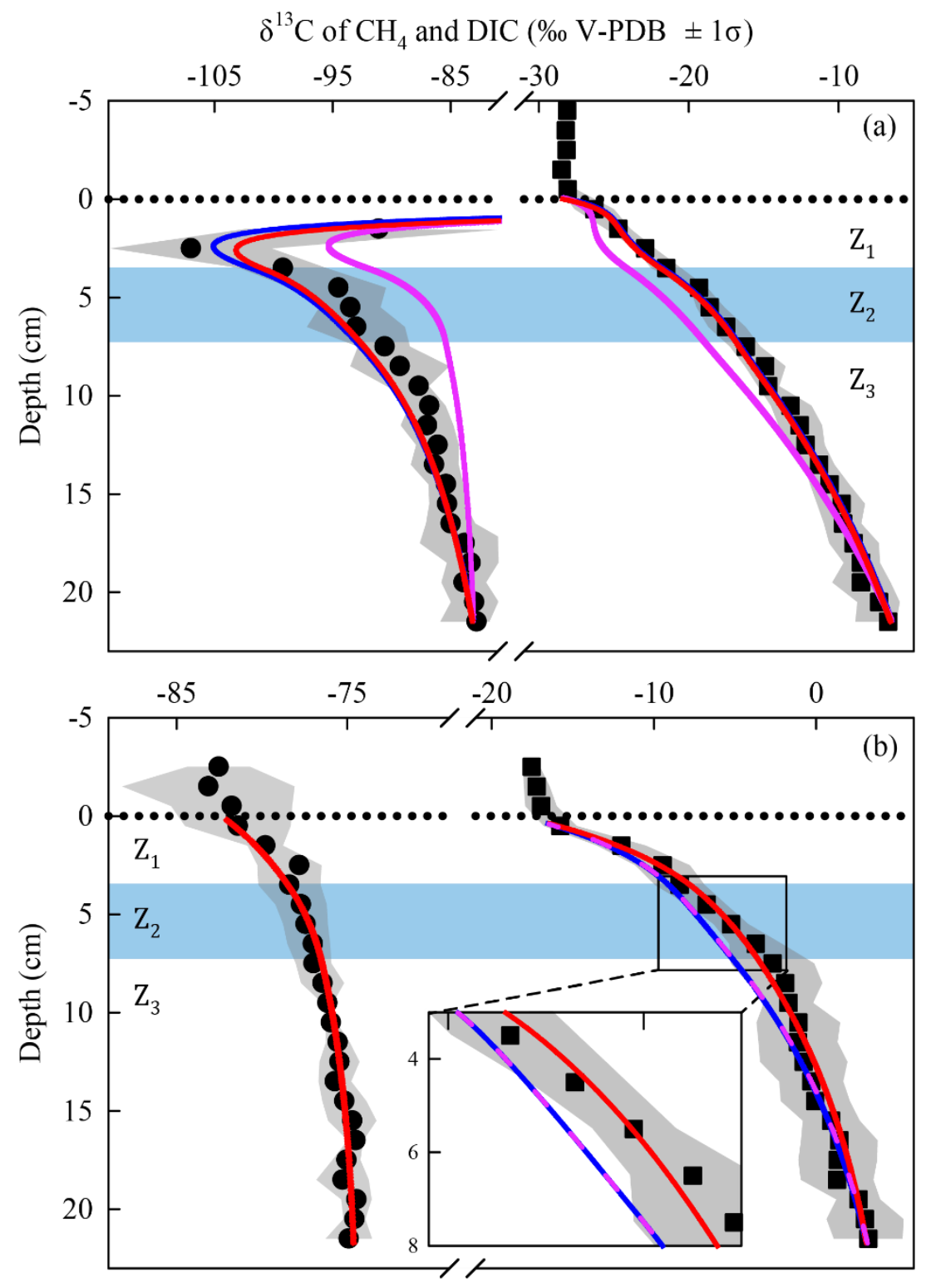

Figure S3: Comparison of the simulated (lines) and measured average $(n=3) \delta^{13} \mathrm{C}$ profiles of $\mathrm{CH}_{4}$ (circles) and DIC (squares) in the porewater of Lake Tantaré Basin A (a) and Lake Bédard (b). The horizontal dotted line indicates the sediment-water interface. The variability in $\delta^{13} \mathrm{C}$ values $( \pm$ one standard deviation $-\sigma$ ) related to the spatial sediment heterogeneity at the sampling sites is shown by the grey area fills around the data points. The zone $Z_{2}$ is delimited by the blue area fill. The purple lines are for the profiles modeled with the default rate and parameter values displayed in tables S1 and $S 2$, the blue lines are for the profiles simulated with the default rate values and optimal $\alpha_{i}$ and $f$ values as described in section S2.2.1, and the red lines are for the profiles modeled with $\chi_{M}=0.75$ (panel a; see section S2.2.2.2 for details) or with $\alpha_{2}$ values of $0.980-0.984$ in the $Z_{2}$ (panel $b$; see section S2.2.3 for details). Note that the blue and red lines are overlapped for the $\delta^{13} \mathrm{C}$-DIC profile in panel a and that the purple, blue and red lines are overlapped for the $\delta^{13} \mathrm{C}-\mathrm{CH}_{4}$ profile in panel b. 


\section{S2.2. Improving the fit between modeled and measured $\delta^{13} \mathrm{C}$ profiles}

\section{S2.2.1. Optimizing the $\alpha_{i}$ and f values}

Additional simulations were achieved using in Eq. 7 the default $\mathrm{R}_{\mathrm{i}}$ values while varying $\alpha_{3}, \alpha_{4}, \alpha_{5}$ and $\mathrm{f}-\mathrm{CH}_{4}$ within the range reported in the literature (Table $\mathrm{S} 1$ ) to improve the fits between the modeled and measured $\delta^{13} \mathrm{C}$ profiles. Two optimization procedures, based on the minimum $\mathrm{N}_{\text {res }}$ values, calculated with Eq. 8 for both the $\delta^{13} \mathrm{C}$ $\mathrm{CH}_{4}$ and the $\delta^{13} \mathrm{C}$-DIC profiles, were used. One, involved varying sequentially by hand first $\alpha_{4}$ and $\alpha_{3}$, and then the less influential parameters, i.e., $\alpha_{5}$ and f- $\mathrm{CH}_{4}$ (see Clayer et al., 2018 for details). The other one used a MATLAB ${ }^{\circledR}$ genetic algorithm of the global optimization toolbox, where the algorithm repeatedly provides a population of parameters within the ranges given in Table $\mathrm{S} 1$ to perform several hundreds of simulations. At each iteration, the genetic algorithm selects the best performing parameters from the current population and uses them as parents to produce the children parameters for the next generation. Over successive generations, the population of parameters "evolves" toward an optimal solution. The two optimization procedures yielded very similar results and thereafter, we used the MATLAB ${ }^{\circledR}$ genetic algorithm to optimize the parameters and reaction rate values. Note that, during optimization for Lake Tantaré Basin A, $\alpha_{4}$ was allowed to take different values in the $\mathrm{Z}_{1}, \mathrm{Z}_{2}$ and $\mathrm{Z}_{3}$.

Figure S3 shows that optimizing the $f$ and $\alpha_{i}$ values greatly improves the fit for Lake Tantaré Basin A only and that the modeled profiles (blue lines in Fig. S3a) capture the main tendencies of the $\delta^{13} \mathrm{C}$ profiles measured in this lake basin. Small discrepancies persist between the modeled and measured profiles (e.g., the $\delta^{13} \mathrm{C}$-DIC profiles for Lake 
Bédard) leaving the possibility that better fits could be reached if more accurate $R_{i}$ values than the default values were selected.

\section{S2.2.2. Optimizing the $R_{i}$ values}

Uncertainties in the $\mathrm{R}_{\mathrm{i}}$ values may result from the assumptions that: i) all the $\mathrm{CH}_{4}$ was produced by hydrogenotrophy in the sediments of both lake basins (sections S2.1.2.1 and $S 2.1 .2 .2$ ), ii) OM oxidation was not a source of DIC in the $Z_{1}$ and $Z_{2}$ of Lake Tantaré Basin A (section S2.1.2.1 and S2.1.2.2), and iii) the fermenting substrate was glucose in the $\mathrm{Z}_{2}$ of Lake Bédard (section $\mathrm{S} 2.1 .2 .2$ ). The mathematical expressions of the $\mathrm{R}_{\mathrm{i}}$ have to be modified if we assume that a proportion of methanogenesis occurs via acetoclasty, that a fraction of DIC is produced through OM oxidation, or if the fermenting substrate is more reduced than glucose. The modified expressions for $\mathrm{R}_{\mathrm{i}}$ are derived below and summarized in Table $S 2$ for the $Z_{1}$ and $Z_{2}$ of both lake basins.

Introducing into Eq. 5, the fraction of oxidants consumed by methanotrophy $\left(\chi_{M}\right)$ which can take any value between 0 and 1 , we can write:

$$
\mathrm{R}_{5}=\frac{1}{2} \chi_{\mathrm{M}} \times\left(-\mathrm{R}_{\mathrm{net}}^{\mathrm{OX}}\right)
$$

and:

$$
\mathrm{R}_{6}=\left(1-\chi_{\mathrm{M}}\right) \times\left(-\mathrm{R}_{\mathrm{net}}^{\mathrm{Ox}}\right)
$$

Combining Eq. 3 and S2, we obtain:

$$
\mathrm{R}_{3}+\mathrm{R}_{4}=\mathrm{R}_{\mathrm{net}}^{\mathrm{CH}_{4}}+\frac{1}{2} \chi_{\mathrm{M}} \times\left(-\mathrm{R}_{\mathrm{net}}^{\mathrm{Ox}}\right)
$$

Introducing into Eq. S4, the fraction of $\mathrm{CH}_{4}$ produced through hydrogenotrophy $\left(\chi_{\mathrm{H}}\right)$, we can write: 


$$
\mathrm{R}_{4}=\chi_{\mathrm{H}}\left(\mathrm{R}_{\mathrm{net}}^{\mathrm{CH}_{4}}-\frac{1}{2} \chi_{\mathrm{M}} \mathrm{R}_{\text {net }}^{\mathrm{Ox}}\right)
$$

and:

$$
\mathrm{R}_{3}=\left(1-\chi_{\mathrm{H}}\right)\left(\mathrm{R}_{\text {net }}^{\mathrm{CH}_{4}}-\frac{1}{2} \chi_{\mathrm{M}} \mathrm{R}_{\mathrm{net}}^{\mathrm{Ox}}\right)
$$

By combining Eqs. 3-5, and assuming that $\mathrm{R}_{7}=0, \mathrm{R}_{1}$ can be expressed:

$$
\mathrm{R}_{1}=\mathrm{R}_{\text {net }}^{\mathrm{DIC}}-\mathrm{R}_{\text {net }}^{\mathrm{CH}_{4}}+\mathrm{R}_{\text {net }}^{\mathrm{Ox}}+2 \mathrm{R}_{4}-\mathrm{R}_{2}
$$

Combining Eqs. S5 and S7, we obtain:

$$
\mathrm{R}_{1}=\mathrm{R}_{\text {net }}^{\mathrm{DIC}}-\mathrm{R}_{\text {net }}^{\mathrm{CH}_{4}}+\mathrm{R}_{\text {net }}^{\mathrm{Ox}}+\chi_{\mathrm{H}}\left(2 \mathrm{R}_{\text {net }}^{\mathrm{CH}_{4}}-\chi_{\mathrm{M}} \mathrm{R}_{\text {net }}^{\mathrm{Ox}}\right)-\mathrm{R}_{2}
$$

The expressions for the ranges of the $\mathrm{R}_{1}-\mathrm{R}_{6}$ values displayed in Table $\mathrm{S} 2$, with the notable exception of $R_{1}$ in the $Z_{2}$ of Lake Bédard, were obtained by substituting into Eqs. S2, S3, S5, S6 and S8 the appropriate values of $\mathrm{R}_{\text {net }}^{\mathrm{CH}_{4}}, \mathrm{R}_{\text {net }}^{\mathrm{DIC}}$ and $\mathrm{R}_{\text {net }}^{\mathrm{Ox}}$ from Table 2. It may be recalled that in deriving these expressions, the following assumptions were made, in accordance with section S2.1.2: i) $\mathrm{R}_{2}=\mathrm{R}_{7}=0$ in the $\mathrm{Z}_{1}$ and $\mathrm{Z}_{2}$ of Lake Tantaré Basin A; ii) $R_{5}=R_{6}=R_{7}=0$ in the $Z_{1}$ and $Z_{2}$ of Lake Bédard; iii) $R_{2}=0$ in the $Z_{1}$, but not in the $Z_{2}$ of Lake Bédard. In order to calculate the values of $R_{1}$ with Eq. $S 8$ for the $Z_{2}$ of Lake Bédard, we had to express $\mathrm{R}_{1}$ as a function of the COS of the fermenting substrate as described below.

The rate of $\mathrm{H}_{2}$ production required through $\mathrm{r} 1$ to sustain hydrogenotrophy is given by:

$$
\left(\frac{4 v_{1}+y-2 z}{2 v_{1}}\right) R_{1}=4 R_{4}
$$

Combining Eqs. S5 and S9, we obtain: 


$$
\mathrm{y}=\left(\frac{2 \chi_{\mathrm{H}}\left(\mathrm{R}_{\text {net }}^{\mathrm{CH}_{4}}-\frac{1}{2} \chi_{\mathrm{M}} \mathrm{R}_{\text {net }}^{\mathrm{Ox}}\right)-\mathrm{R}_{1}}{\mathrm{R}_{1}}\right) 4 v_{1}+2 \mathrm{z}
$$

The rate of acetate production through $\mathrm{r} 1$ (Table 1) to sustain acetoclasty is given by:

$$
\left(\frac{\mathrm{x}-v_{1}}{2 v_{1}}\right) \mathrm{R}_{1}=\mathrm{R}_{3}
$$

Combining Eqs. S6 and S11, we can write:

$$
v_{1}=\frac{\mathrm{xR}_{1}}{2\left(1-\chi_{\mathrm{H}}\right)\left(\mathrm{R}_{\text {net }}^{\mathrm{CH}_{4}}-\frac{1}{2} \chi_{M} \mathrm{R}_{\text {net }}^{\mathrm{Ox}}\right)+\mathrm{R}_{1}}
$$

Replacing $v_{1}$ in Eq. S10 by its expression in Eq. S12, we obtain:

$$
y=\left(\frac{2 \mathrm{R}_{1} \chi_{\mathrm{H}}\left(\mathrm{R}_{\text {net }}^{\mathrm{CH}_{4}}-\frac{1}{2} \chi_{\mathrm{M}} \mathrm{R}_{\text {net }}^{\mathrm{OX}}\right)-\mathrm{R}_{1}{ }^{2}}{2 \mathrm{R}_{1}\left(1-\chi_{\mathrm{H}}\right)\left(\mathrm{R}_{\text {net }}^{\mathrm{CH}_{4}}-\frac{1}{2} \chi_{\mathrm{M}} \mathrm{R}_{\text {net }}^{\mathrm{Ox}}\right)+\mathrm{R}_{1}{ }^{2}}\right) 4 \mathrm{x}+2 \mathrm{z}
$$

The COS of an organic molecule is given by:

$$
\cos =-\sum_{i} \operatorname{OS}_{i} \frac{\mathrm{n}_{i}}{\mathrm{n}_{c}}
$$

where $\mathrm{OS}_{i}$ is the oxidation state of the element $i$ and $\mathrm{n}_{i} / \mathrm{n}_{c}$ is its molar ratio to carbon.

Assuming that the $\mathrm{COS}$ of the fermenting molecule is defined only by $\mathrm{H}$ and $\mathrm{O}$ atoms, whose OS are respectively +1 and -2 , it can be written:

$$
\operatorname{COS}=-\left(\frac{\left[\left(\frac{2 \mathrm{R}_{1} \chi_{\mathrm{H}}\left(\mathrm{R}_{\mathrm{net}}^{\mathrm{CH}_{4}}-\frac{1}{2} \chi_{\mathrm{M}} \mathrm{R}_{\mathrm{net}}^{\mathrm{Ox}}\right)-\mathrm{R}_{1}{ }^{2}}{2 \mathrm{R}_{1}\left(1-\chi_{\mathrm{H}}\right)\left(\mathrm{R}_{\mathrm{net}}^{\mathrm{CH}}-\frac{1}{2} \chi_{\mathrm{M}} \mathrm{R}_{\mathrm{net}}^{\mathrm{OX}}\right)+\mathrm{R}_{1}{ }^{2}}\right) 4 \mathrm{x}+2 \mathrm{z}\right] \times(+1)+(\mathrm{z}) \times(-2)}{\mathrm{x}}\right)
$$

Eq. S15 can be simplified as:

$$
\mathrm{R}_{1}\left(2 \operatorname{COS}\left(1-\chi_{\mathrm{H}}\right)+8 \chi_{\mathrm{H}}\right)\left(\mathrm{R}_{\mathrm{net}}^{\mathrm{CH}_{4}}-\frac{1}{2} \chi_{\mathrm{M}} \mathrm{R}_{\mathrm{net}}^{\mathrm{Ox}}\right)+(\operatorname{COS}-4) \mathrm{R}_{1}{ }^{2}=0
$$

Eq. $\mathrm{S} 16$ has two solutions which are $\mathrm{R}_{1}=0$, and: 


$$
\mathrm{R}_{1}=\frac{\left(2 \operatorname{Cos}\left(1-\chi_{\mathrm{H}}\right)+8 \chi_{\mathrm{H}}\right)\left(\frac{1}{2} \chi_{\mathrm{M}} \mathrm{R}_{\mathrm{net}}^{\mathrm{Ox}}-\mathrm{R}_{\text {net }}^{\mathrm{CH}_{4}}\right)}{\operatorname{CoS}-4}
$$

The expression of $\mathrm{R}_{1}$ for the $\mathrm{Z}_{2}$ of Lake Bédard given in Table $\mathrm{S} 2$ was obtained by substituting into Eq. $\mathrm{S} 17$ the appropriate values of $\mathrm{R}_{\text {net }}^{\mathrm{CH}_{4}}$ and $\mathrm{R}_{\text {net }}^{\mathrm{Ox}}$ from Table 2, and that of $\mathrm{R}_{2}$ using Eq. S8.

Below, the general expressions of $\mathrm{R}_{1}-\mathrm{R}_{6}$ displayed in Table $\mathrm{S} 2$ for the $\mathrm{Z}_{1}$ and $\mathrm{Z}_{2}$ of both lake basins are used to perform additional $\delta^{13} \mathrm{C}$ simulations and examine the effect of varying the values of $\chi_{\mathrm{H}}, \chi_{\mathrm{M}}$ and $\mathrm{COS}$ on the modelled $\delta^{13} \mathrm{C}$ profiles.

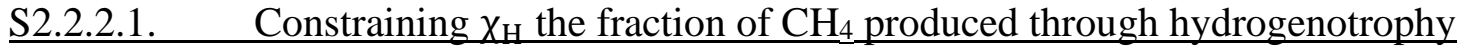

Figure $\mathrm{S} 4 \mathrm{a}$ and $\mathrm{b}$ displays the $\mathrm{N}_{\text {res }}$ values for $\delta^{13} \mathrm{C}$ simulations with $\chi_{\mathrm{H}}$ comprised between 0.8 and 1 in the $Z_{1}$ and $Z_{2}$ of both lake basins. Note that the $f$ and $\alpha_{i}$ values were optimized as described in section S2.2.1 for each $\chi_{H}$ value tested. Whereas, the $\mathrm{N}_{\text {res }}$ of the $\delta^{13} \mathrm{C}-\mathrm{CH}_{4}$ for Lake Tantaré Basin A and Lake Bédard does not vary with $\chi_{\mathrm{H}}$ (dotted blue line in Fig. S4a and b), that of the $\delta^{13} \mathrm{C}$-DIC increases significantly as the value of $\chi_{\mathrm{H}}$ decreases (dashed blue line in Fig. S4a and b). This finding supports our contention that the contribution of acetoclasty to methanogenesis is negligible in both lake basins, i.e., $\chi_{\mathrm{H}}=1$ (see section 3.3 and Fig. S2). 
Lake Tantaré Basin A
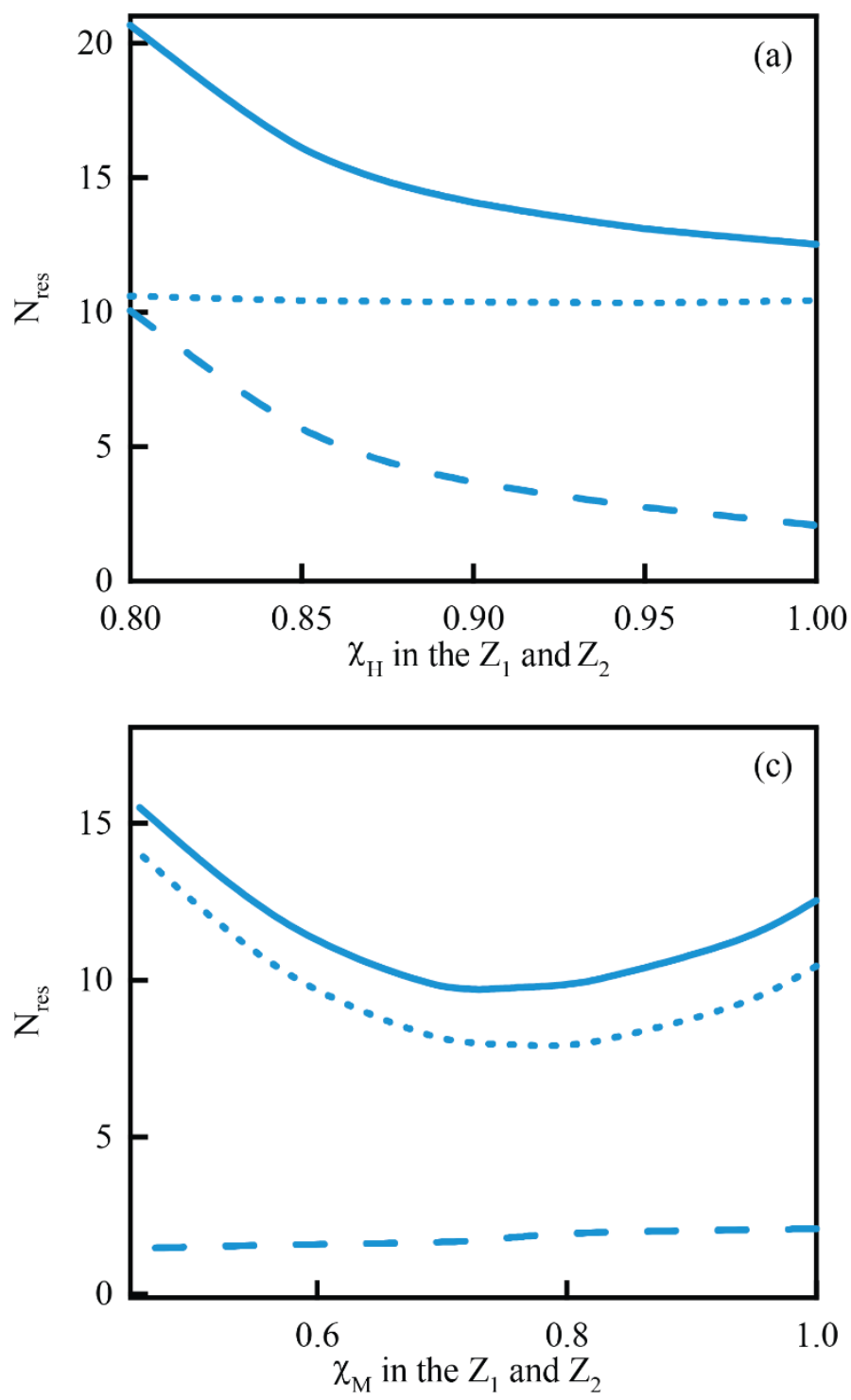

Lake Bédard
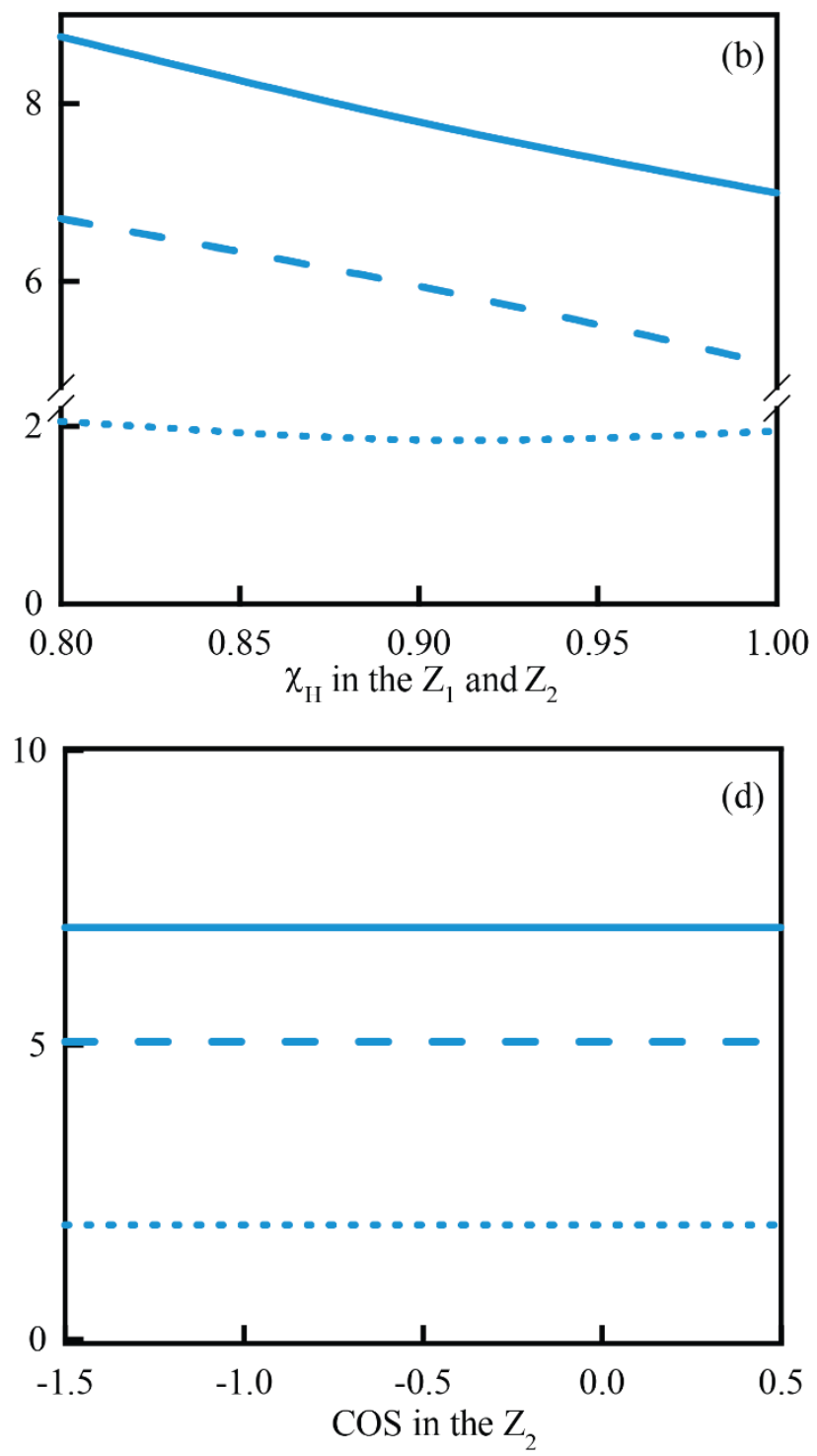

Figure S4: Norm of residuals $\left(\mathrm{N}_{\mathrm{res}}\right)$, calculated with Eq. (8), for the $\delta^{13} \mathrm{C}$-DIC (dashed line) and the $\delta^{13} \mathrm{C}_{-} \mathrm{CH}_{4}$ (dotted line) profiles, and the sum of $\mathrm{N}_{\text {res }}$ for the two profiles (solid lines). In panels a and $\mathrm{b}$, the $N_{r e s}$ values are displayed as a function of $\chi_{H}$ for the $Z_{1}$ and $Z_{2}$ of both lake basins, in panel $c$, as a function of $\chi_{M}$ for the $Z_{1}$ and $Z_{2}$ of Lake Tantaré Basin $A$, and in panel $d$, as a function of the COS for the $Z_{2}$ of Lake Bédard. 
S2.2.2.2. Constraining $\chi_{M}$ the fraction of oxidant consumed through methanotrophy

In section $\mathrm{S} 2.1 .2 .2$, we neglected OM oxidation as a source of DIC in the $\mathrm{Z}_{1}$ and $\mathrm{Z}_{2}$ of Lake Tantaré Basin A. Figure $\mathrm{S} 4 \mathrm{c}$ shows that the sum of $\mathrm{N}_{\text {res }}$ for the $\delta^{13} \mathrm{C}_{-} \mathrm{CH}_{4}$ and the $\delta^{13} \mathrm{C}$-DIC profile displays a minimum at a $\chi_{\mathrm{M}}$ value of about 0.75 , when $\chi_{\mathrm{M}}$ is varied between 0.36 and 1 , while maintaining $\chi_{\mathrm{H}}$ at 1 and optimizing the $f$ and $\alpha_{\mathrm{i}}$ as in section S2.2.1. Fig S3a (red line) shows that using $\chi_{M}=0.75$ in the simulation results in a slightly improved fit of the $\delta^{13} \mathrm{C}_{-} \mathrm{CH}_{4}$ profile. This $\chi_{M}$ value implies that about $25 \%$ of the oxidant are consumed through OM oxidation in the $\mathrm{Z}_{1}$ and $\mathrm{Z}_{2}$ of Lake Tantaré Basin $\mathrm{A}$. Assuming that $\chi_{M}=0.75$, we calculate with the equations reported in Table S2 that: $R_{1}=$ $132 \mathrm{fmol} \mathrm{cm}{ }^{-3} \mathrm{~s}^{-1}, \mathrm{R}_{4}=119 \mathrm{fmol} \mathrm{cm}{ }^{-3} \mathrm{~s}^{-1}, \mathrm{R}_{5}=126 \mathrm{fmol} \mathrm{cm}^{-3} \mathrm{~s}^{-1}$ and $\mathrm{R}_{6}=84 \mathrm{fmol} \mathrm{\textrm {cm } ^ { - 3 }}$

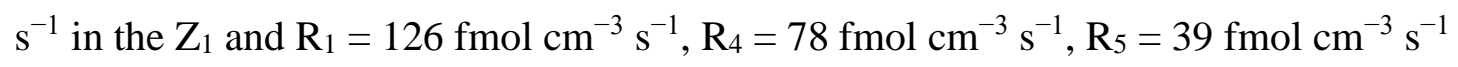
and $\mathrm{R}_{6}=26 \mathrm{fmol} \mathrm{cm} \mathrm{s}^{-3}$ in the $\mathrm{Z}_{2}$ (Table 3).

\section{S2.2.2.3. Influence of the $\operatorname{COS}$ in the $\mathrm{Z}_{2}$ of Lake Bédard}

Figure S4d shows that varying the value of the COS between -1.5 and +0.5 , while maintaining $\chi_{\mathrm{H}}$ at 1 and optimizing the $\mathrm{f}$ and $\alpha_{\mathrm{i}}$ as in section $\mathrm{S} 2.2 .1$ has no influence on the modelled $\delta^{13} \mathrm{C}$ profiles, i.e., it yields similar $\mathrm{N}_{\text {res }}$ values. This result was expected given that the COS only affects the values of $\mathrm{R}_{1}$ and $\mathrm{R}_{2}$ and that we assumed no fractionation for reactions $\mathrm{r} 1$ and $\mathrm{r} 2$, as generally proposed in the literature (Lapham et al., 1999; Werth and Kusyakov, 2010; Conrad et al., 2012; Corbet et al., 2015). However, Fig. S3b exhibits a discrepancy between the measured and modeled $\delta^{13} \mathrm{C}$-DIC profiles of Lake Bédard. To test if an isotopic fractionation of the DIC assumed to be produced by partial fermentation of HMW OM in the $\mathrm{Z}_{2}$ of lake Bédard, could explain this discrepancy, we varied $\alpha_{2}$ in the simulations. Figure S5 reveals that a minimum $\mathrm{N}_{\text {res }}$ is 
obtained at a value of $\alpha_{2}=0.980$ for a COS value of 0 , as assumed in section S2.1.2.2, and Fig. S3b (red line) shows that using this $\alpha_{2}$ value in the simulation results in an improved fit of the $\delta^{13} \mathrm{C}$-DIC profile for Lake Bédard. The optimum $\alpha_{2}$ value vary slightly with the COS value inferred. For example, for a $\operatorname{COS}$ value of -1.5 , the optimum $\alpha_{2}$ value would be 0.984 (Fig. S5). Varying the COS within reasonable values, however, does not influence significantly the fitting of the $\delta^{13} \mathrm{C}$-DIC profile for Lake Bédard shown by the red line in Fig. S3d. Assuming that the COS $=-1.5$ in the $Z_{2}$ of Lake Bédard, we calculate with the equations reported in Table S2 that: $R_{1}=72 \mathrm{fmol} \mathrm{cm}^{-3} \mathrm{~s}^{-1}, \mathrm{R}_{2}=145$ fmol cm${ }^{-3} \mathrm{~s}^{-1}$ and $\mathrm{R}_{4}=50 \mathrm{fmol} \mathrm{cm} \mathrm{s}^{-3}$ (Table 3). Note that, considering an $\alpha_{2}$ value between 0.980 and 0.984 for the DIC produced through reaction $\mathrm{r} 2$ and a $\delta^{13} \mathrm{C}$ signature of $-28 \%$ for the HMW OM is equivalent to assuming no isotopic fractionation (i.e., $\alpha_{2}=$ 0 ) and a $\delta^{13} \mathrm{C}$ signature of $-8 \%$ to $-12 \%$ for the source material.

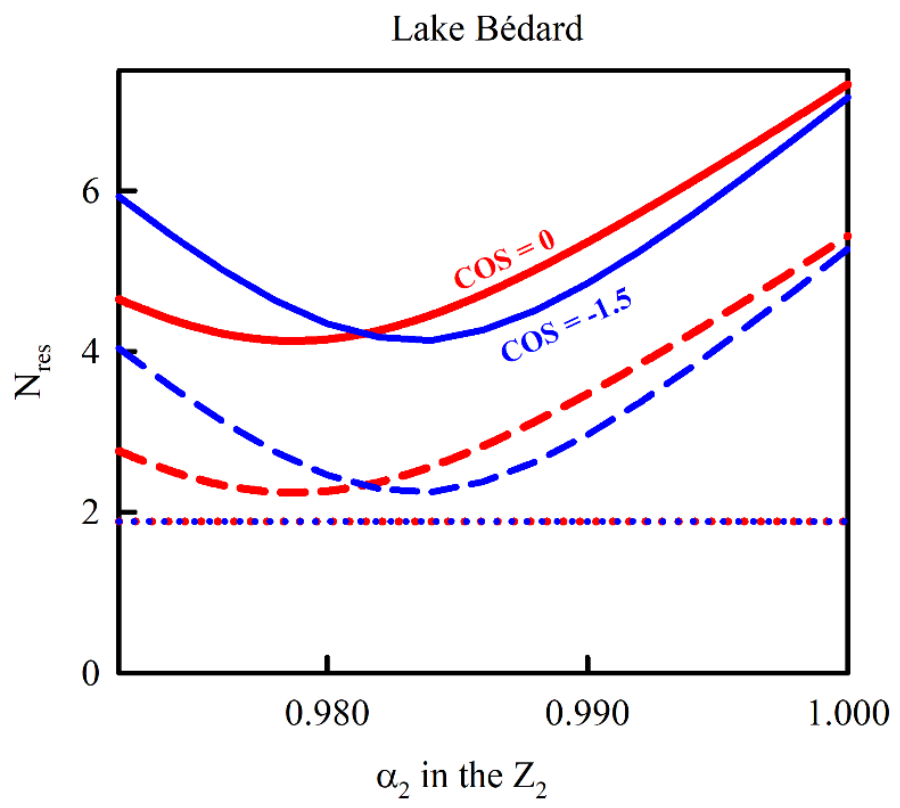

Figure S5: Norm of residuals $\left(\mathrm{N}_{\text {res }}\right)$, calculated with Eq. $(8)$, for the simulated $\delta^{13} \mathrm{C}$-DIC (dashed line) and the $\delta^{13} \mathrm{C}_{-} \mathrm{CH}_{4}$ (dotted line) profiles, and the sum of $\mathrm{N}_{\text {res }}$ for the two profiles (solid line) as a function of the value of $\alpha_{2}$ in the $Z_{2}$ of Lake Bédard. 


\section{S3. Other data from Lakes Tantaré, Bédard, Jacks and Lugano used to calculate the COS.}

\section{S3.1. Relevant data available and lake characteristics.}

Porewater profiles of solutes relevant to the COS calculation, measured by our group in Lakes Tantaré and Bédard at other dates than in the present study, are available from our earlier publications or from our data repository. Profiles of porewater $\mathrm{CH}_{4}, \mathrm{DIC}$, $\mathrm{SO}_{4}{ }^{2-}$, sulfides $(\Sigma \mathrm{S}(-\mathrm{II}))$ and $\mathrm{Fe}$, determined at the deepest site in the perennially oxic Basin A of Lake Tantaré in September 2004, October 2005, September 2006 and July 2012, have been reported by Clayer et al. (2016). Vertical profiles of the same solutes measured at the deepest site in the sediments of Basin B of Lake Tantaré in October 2006, July 2007, October 2011 and October 2014 can also be found in Clayer et al. (2016 and 2018); the $\delta^{13} \mathrm{C}$ profiles of $\mathrm{CH}_{4}$ and DIC are also provided for the October 2014 campaign (Clayer et al. 2018). Basins A and B of Lake Tantaré, the two westernmost basins of Lake Tantaré, are connected by a shallow channel. This lake is oligotrophic, with a planktonic primary production of $50 \mathrm{mg} \mathrm{C} \mathrm{m}^{-2} \mathrm{~d}^{-1}$ measured in Basin A (Hare et al. 1994). Bottom water in Basin B, in contrast to that of Basin A, becomes occasionally anoxic in late summer (Couture et al., 2008). Also, its ${ }^{210} \mathrm{~Pb}$ profile reveals no mixing in the uppermost sediment layers and the ${ }^{137} \mathrm{Cs},{ }^{241} \mathrm{Am}$ and mid- $19^{\text {th }}$ century Upper Mississippi Valley $\mathrm{Pb}$ isotope chronostratigraphic markers, all display sharp peaks (Gobeil et al., 2013). Collectively, these observations indicate that benthic invertebrates are virtually absent at that site and that solute transport across the sediment-water interface (SWI) should be by molecular diffusion alone. Couture et al. (2010) provide

porewater $\mathrm{SO}_{4}{ }^{2-}, \Sigma \mathrm{S}(-\mathrm{II})$ ), and Fe profiles determined in June 2004 at the deepest site in 
Lake Bédard, and an unpublished set of porewater profiles of $\mathrm{CH}_{4}, \mathrm{DIC}, \mathrm{SO}_{4}{ }^{2-}, \Sigma \mathrm{S}(-\mathrm{II})$ and Fe obtained in October 2003 by our group with the methods described by Clayer et al. (2016) is also available from our archives. The profiles of ${ }^{210} \mathrm{~Pb},{ }^{137} \mathrm{Cs}$, and stable $\mathrm{Pb}$ isotope (Gobeil et al., 2013) all point out to the absence of benthic invertebrates in Lake Bédard sediments.

Carignan and Lean (1991) reported porewater DIC, $\mathrm{CH}_{4}, \mathrm{NH}_{4}, \Sigma \mathrm{S}(-\mathrm{II}), \mathrm{P}, \mathrm{Si}, \mathrm{Fe}$, Mn, Ca, Mg, K and pH profiles obtained in September 1981 with peepers at 5 sites of varying depth $(4,10,15,20.2$ and $21.7 \mathrm{~m})$ along a transect in the Williams Bay of Jacks Lake $\left(44^{\circ} 41^{\prime} \mathrm{N}, 78^{\circ} 02^{\prime} \mathrm{W}\right)$. This lake is located $\sim 65 \mathrm{~km}$ north of Peterborough, Ontario, on the fringe of the Canadian Shield and the bedrock of its forested watershed comprises mainly felsic rocks with minor limestone outcroppings (Pick et al., 1984). The dimictic Williams Bay is mesotrophic, with a ${ }^{14} \mathrm{C}$ primary production of $\sim 900 \mathrm{mg} \mathrm{C} \mathrm{m}^{-2} \mathrm{~d}^{-1}$, and it develops an anoxic hypolimnion from mid-June to September. The presence of $\Sigma \mathrm{S}(-\mathrm{II})$ in the water overlying the sediments indicates anoxia at the sediment surface of all stations in September. Carignan and Lean (1991) mention that macrobenthos activity at the two shallowest stations should be suspected from the ${ }^{210} \mathrm{~Pb}$ and the $\mathrm{DIC}$ and $\mathrm{CH}_{4}$ profiles, and that a loss of $\mathrm{CH}_{4}$ may have occurred during retrieval and sampling of the peepers and have altered the lower part (below $\sim 30 \mathrm{~cm}$ ) of the $\mathrm{CH}_{4}$ profiles at the three deepest stations. The authors identified by SEM/EDAX solid Fe sulfide particles $\left(\mathrm{FeS}_{2(\mathrm{~s})}\right.$ and $\left.\mathrm{FeS}_{(\mathrm{s})}\right)$ in the sediments of the three deepest stations but were unable to detect carbonates $\left(\mathrm{FeCO}_{3(\mathrm{~s})}\right.$ or $\left.\mathrm{CaCO}_{3(\mathrm{~s})}\right)$.

Porewater profiles of $\mathrm{CH}_{4}, \mathrm{DIC}, \mathrm{Ca}, \mathrm{Fe}, \mathrm{SO}_{4}{ }^{2-}$ and $\Sigma \mathrm{S}(-\mathrm{II})$ have been obtained with peepers (Lazzaretti et al., 1992; Lazzaretti-Ulmer and Hanselmann, 1999) in June 
1989, September 1989 and March 1990 at two sites (Melide, $85 \mathrm{~m}$ depth and Figino, 95

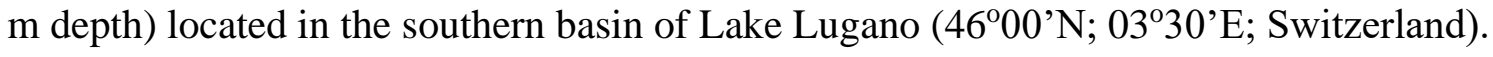
This lake basin is monomictic, with the overturn occurring in February. It was originally oligotrophic but it had become eutrophic in 1989 for more than 30 years due to increasing nutrient loads, and it showed a primary production rate of up to $\sim 1260 \mathrm{mg} \mathrm{C} \mathrm{m}^{-2} \mathrm{~d}^{-1}$ (Barberi and Mosello, 1992; Niessen et al., 1992). As shown in the papers by Lazzaretti et al. (1992) and Lazzaretti-Ulmer and Hanselmann (1999), the redox conditions at the SWI varied markedly with time. In the overlying water, in March 1990, $\left[\mathrm{O}_{2}\right]$ concentration was $\sim 2$ and $4 \mathrm{mg} \mathrm{L}^{-1}$ at the Figino and Melide sites, respectively, and $\Sigma \mathrm{S}(-\mathrm{II}), \mathrm{CH}_{4}, \mathrm{Fe}(\mathrm{II})$ and $\mathrm{Mn}(\mathrm{II})$ were absent in the lake bottom water, supporting oxidizing conditions at the SWI at the two sites at that date. In contrast, in June and September 1989, the SWI at the two sites was anoxic since $\Sigma \mathrm{S}$ (-II), $\mathrm{CH}_{4}, \mathrm{Fe}$ (II) and $\mathrm{Mn}(\mathrm{II})$ were present in the overlying water (except Fe in June at the Figino site). The sediments at the two sites are characterized by the presence of carbonate and clay varves (Span et al., 1992) and by the absence of benthos remains in the pre-1970 layers (Niessen et al., 1992), indicating the absence on benthic animals.

\section{S.3.2. Data treatment}

The relevant porewater profiles for Lake Bédard and for the two basins of Lake Tantaré were gathered from our archives or from our earlier publications. For Williams Bay of Jacks Lake and for Lake Lugano, the published plots of the porewater solutes of interest were enlarged electronically, and the coordinates of the data points were determined to reconstruct the solute concentration vs depth profiles. The measured $\mathrm{CH}_{4}$ and DIC profiles for Lakes Tantaré, Bédard, Jacks (Williams Bay) and Lugano along 
with their respective modeled profiles using the code PROFILE are displayed in Fig. 4. For Williams Bay, only the profiles reported at $15 \mathrm{~m}$ and $22 \mathrm{~m}$ were retained in this study; those from the two shallowest sites $(4 \mathrm{~m}$ and $10 \mathrm{~m})$ were ignored because of sediment bioirrigation (Carignan and Lean 1991), whereas those from the 20-m site were discarded because modeling with PROFILE predicted an extremely low net DIC production rate. For Lake Lugano, the data pertaining to March 1990 and June 1989 were kept; those reported for September 1989 were rejected because the $\mathrm{CH}_{4}$ and DIC concentration profiles were almost linear and modeling with PROFILE did not show any zone of significant net $\mathrm{CH}_{4}$ production. The $\mathrm{R}_{\text {net }}^{\mathrm{Ox}}$ values were calculated, as described in section 2.3, from the consumption rates of the electron acceptors (EAs; $\mathrm{O}_{2}, \mathrm{Mn}(\mathrm{IV})$, $\mathrm{Fe}(\mathrm{III})$ and $\mathrm{SO}_{4}{ }^{2-}$ ) obtained by modeling the porewater depth distributions of $\mathrm{O}_{2}, \mathrm{Mn}(\mathrm{II})$, $\mathrm{Fe}(\mathrm{II})$ and $\mathrm{SO}_{4}{ }^{2-}$ with the code PROFILE. To estimate the contribution of the $\mathrm{O}_{2}$ consumption rate to $\mathrm{R}_{\text {net }}^{\mathrm{Ox}}$ in March at the two sites of Lake Lugano, we assumed that the $\left[\mathrm{O}_{2}\right]$ at the sediment surface was $2 \mathrm{mg} . \mathrm{L}^{-1}$ at Figino and $4 \mathrm{mg} . \mathrm{L}^{-1}$ at Mélide, i.e., the concentrations measured in the water column, near the sediment surface at these sites (Lazzaretti et al, 1992). The absence of sulfate data for Williams Bay prevented us from calculating $\mathrm{R}_{\text {net. }}^{\mathrm{Ox}}$. The production rate of DIC due to carbonate dissolution in the porewaters was calculated by modeling with PROFILE the porewater Ca profiles for the two sites in Lake Lugano, and its contribution was removed from the $\mathrm{R}_{\text {net }}^{\mathrm{DIC}}$; this calculation was unnecessary for Williams Bay where this dissolution reaction did not occur. In modeling with PROFILE, we assumed that $\alpha_{\text {irrigation }}$ was negligible, even in March for the two sites at Lake Lugano, given the evidence that macrobenthos is absent. Note that the $\mathrm{R}_{\text {net }}^{\mathrm{DIC}}$ and $\mathrm{R}_{\text {net }}^{\mathrm{Ox}}$ values are weighed average values calculated over a zone of net methanogenesis. The $\mathrm{R}_{\text {net }}^{\mathrm{CH}_{4}}, \mathrm{R}_{\text {net }}^{\mathrm{DIC}}$ and $\mathrm{R}_{\text {net }}^{\mathrm{OX}}$ values are regrouped in Table 4 for the various lake basins. 


\section{$\underline{\text { References }}$}

Alperin M.J., Reeburgh W.S. and Whiticar M.J. (1988) Carbon and hydrogen isotope fraction resulting from anaerobic methane oxidation. Global Biogeochem. Cycles 2: 279-288.

Barberi A. and Mosello R. (1992) Chemistry and trophic evolution of Lake Lugano in relation to nutrient budget. Aquatic Sci. 54: 219-237.

Blair N.E. and Carter J.W.D. (1992) The carbon isotope biogeochemistry of acetate from a methanogenic marine sediment. Geochim. Cosmochim. Acta 56: 1247-1258.

Bottinga Y. (1969) Calculated fractionation factors for carbon and hydrogen isotope exchange in the system calcite-carbon dioxide-graphite-methane-hydrogen-water vapor. Geochim. Cosmochim. Acta 33: 49-64.

Carignan R. and Lean D.R.S. (1991) Regeneration of dissolved substances in a seasonally anoxic lake: the relative importance of processes occurring in the water column and in the sediments. Limnol. Oceanogr. 36: 683-707.

Clayer F., Gobeil C. and Tessier A. (2016) Rates and pathways of sedimentary organic matter mineralization in two basins of a boreal lake: emphasis on methanogenesis and methanotrophy. Limnol. Oceanogr. 61: S131-S149.

Clayer F., Moritz A., Gélinas Y., Tessier A. and Gobeil C. (2018) Modeling the carbon isotope signatures of methane and dissolved inorganic carbon to unravel mineralization pathways in boreal lake sediments. Geochim. Cosmochim. Acta 229: 36-52.

Conrad R., Chan O.C., Claus P. and Casper P. (2007) Characterization of methanogenic Archaea and stable isotope fractionation during methane production in the profundal sediment of an oligotrophic lake (Lake Stechlin, Germany). Limnol. Oceanogr. 52: 1393-1406.

Conrad R., Klose M., Yuan Q., Lu Y. and Chidthaisong A. (2012) Stable carbon isotope fractionation, carbon flux partitioning and priming effects in anoxic soils during methanogenic degradation of straw and soil organic matter. Soil Biol. Biochem. 49: 193199.

Conrad R., Claus P., Chidthaisong A., Lu Y., Fernandez Scavino A., Liu Y., Angel R., Galand P.E., Casper P., Guerin F. and Enrich-Prast A. (2014) Stable carbon isotope biogeochemistry of propionate and acetate in methanogenic soils and lake sediments. Org. Geochem. 73: 1-7.

Corbett J.E., Tfaily M.M., Burdige D.J., Glaser P.H. and Chanton J.P. (2015) The relative importance of methanogenesis in the decomposition of organic matter in northern peatlands. J. Geophys. Res.: Biogeosci. 120: 280-293.

Couture R.-M., Gobeil C. and Tessier A. (2008) Chronology of atmospheric deposition of arsenic inferred from reconstructed sedimentary records. Environ. Sci. Technol. 42: 6508-6513.

Couture R.-M., Gobeil C. and Tessier A. (2010) Arsenic, iron and sulfur co-diagenesis in lake sediments. Geochim. Cosmochim. Acta 74: 1238-1255.

Emrich K., Ehhalt D.H. and Vogel J.C. (1970) Carbon isotope fractionation during the precipitation of calcium carbonate. Earth. Planet. Sci. Lett. 8: 363-371.

Gelwicks J.T., Risatti J.B. and Hayes J.M. (1994) Carbon isotope effects associated with aceticlastic methanogenesis. Appl Environ Microbiol 60: 467-472.

Gobeil C., Tessier A. and Couture, R.-M. (2013) Upper Mississippi Pb as a mid-1800s chronostratigraphic marker in sediments from seasonally anoxic lakes in Eastern Canada. Geochim. Cosmochim. Acta 113: 125-135.

Happell J.D., Chanton J.P. and Showers W.J. (1995) Methane transfer across the water-air interface in stagnant wooded swamps of Florida: Evaluation of mass-transfer coefficients and isotopic fractionation. Limnol. Oceanogr. 40: 290-298. 
Hare L., Carignan R. and M. A. Huerta-Diaz (1994) A field study of metal toxicity and accumulation by benthic invertebrates; implications for the acid-volatile sulfide (AVS) model. Limnol. Oceanogr. 39: 1653-1668.

Hélie J.-F. (2004) Géochimie et flux de carbone organique et inorganique dans les milieux aquatiques de l'est du Canada : exemples du Saint-Laurent et du réservoir RobertBourassa -approche isotopique -. Ph.D. thesis, Université du Québec à Montréal.

Jähne B., Heinz G. and Dietrich W. (1987) Measurement of the diffusion coefficients of sparingly soluble gases in water. J. Geophys. Res. 92: 10767-10776.

Joshani A. (2015) Investigating organic matter preservation through complexation with iron oxides in Lake Tantaré. M.Sc. thesis, Concordia University.

Krzycki J.A., Kenealy W.R., DeNiro M.J. and Zeikus J.G. (1987) Stable carbon isotope fractionation by Methanosarcina barkeri during methanogenesis from acetate, methanol, or carbon dioxide-hydrogen. Appl Environ Microbiol 53: 2597-2599.

Lapham L., Proctor L. and Chanton J. (1999) Using respiration rates and stable carbon isotopes to monitor the biodegradation of orimulsion by marine benthic bacteria. Environ. Sci. Technol. 33: 2035-2039.

Lazzaretti M.A., Hanselmann K.W., Brandl H., Span D. and Bachofen R. (1992) The role of sediments in the phosphorus cycle in Lake Lugano. II. Seasonal and spatial variability of microbiological processes at the sediment-water interface. Aquatic Sci. 54: 285-299.

Lazzaretti-Ulmer M.A. and Hanselmann K.W. (1999) Seasonal variation of the microbially regulated buffering capacity at sediment-water interfaces in a freshwater lake. Aquatic Sci. 61: 50-74.

Mook W. G., Bommerson J. C. and Staverman W. H. (1974) Carbon isotope fractionation between dissolved bicarbonate and gaseous carbon dioxide. Earth Planet. Sci. Lett. 22: 169-176.

Niessen F., Wick L., Bonani G., Chondrogianni C. and Siegenthaler C. (1992) Aquatic system response to climatic and human changes: productivity, bottom water oxygen status, and sapropel formation in Lake Lugano over the last 10000 years. Aquatic Sci. 54: 257-276.

O'Leary M.H. (1984) Measurement of the isotope fractionation associated with diffusion of carbon dioxide in aqueous solution. J. Phys. Chem. 88: 823-825.

Pick F.R., Lean D.R.S. and Nalewajko C. (1984) Nutrient status of metalimnetic phytoplankton peaks. Limnol. Oceanogr. 29: 960-971.

Span D., Dominik J., Lazzaretti M.A. and Vernet J.-P. (1992) The role of sediments in the phosphorus cycle in Lake Lugano. I. Geochemical approach. Aquatic Sci. 54: 277-284.

Werth M. and Kuzyakov Y. (2010) ${ }^{13} \mathrm{C}$ fractionation at the root-microorganisms-soil interface: A review and outlook for partitioning studies. Soil Biol. Biochem. 42: 1372-1384.

Whiticar M.J. (1999) Carbon and hydrogen isotope systematics of bacterial formation and oxidation of methane. Chem. Geol. 161: 291-314.

Whiticar M.J. and Faber E. (1986) Methane oxidation in sediment and water column environments-Isotope evidence. Org. Geochem. 10: 759-768. 